\title{
Entrevista: Herval Pina Ribeiro, Francisco Antonio de Castro Lacaz, Carlos Aparício Clemente e Pérsio Dutra falam sobre a história do DIESAT
}

\begin{abstract}
Nesta edição dos Cadernos de Psicologia Social do Trabalho apresentamos uma entrevista com quatro pessoas: os médicos Herval Pina Ribeiro ${ }^{1}$ e Francisco Antonio de Castro Lacaz ${ }^{2}$ e os sindicalistas Carlos Aparício Clemente ${ }^{3}$ e Pérsio Dutra [Peninha $]^{4}$. A entrevista apresenta o DIESAT [Departamento Intersindical de Estudos e Pesquisas de Saúde e dos Ambientes de Trabalho $]^{5}$, órgão criado em 1980 com o objetivo de assessorar entidades sindicais de trabalhadores na área de Saúde do Trabalhador. Herval, Lacaz e Clemente participaram da criação do órgão e Peninha é, atualmente, diretor do DIESAT ${ }^{6}$. Muitas outras pessoas atuaram e atuam no DIESAT: sindicalistas, médicos, engenheiros, advogados, ergonomistas, sociólogos, psiquiatras, psicólogos e jornalistas e, no decorrer da entrevista, algumas delas serão citadas. Como nos falou Herval Pina Ribeiro, mais do que relatar essa história, esse encontro foi uma oportunidade para refletir e para interpretar o DIESAT. Também, como disse ele, a Saúde do Trabalhador no Brasil não se restringe ao DIESAT; entretanto, esse órgão é um dos porta-vozes do discurso da Saúde do Trabalhador. A entrevista foi realizada por Leny Sato, em São Paulo, no dia primeiro dia de julho de 2003. Para a psicologia, o DIESAT constituiu-se em um espaço importante, pois, o discurso da Saúde do Trabalhador possibilitou que ela olhasse o Trabalho e a Saúde a partir da perspectiva de quem trabalha, tendo sido, sem dúvida, uma importante âncora para uma prática comprometida com os problemas humanos no trabalho, abrigando também uma das possibilidades para traçar uma outra trajetória para a psicologia do trabalho e da saúde no Brasil, a partir da leitura da psicologia social ${ }^{7}$.
\end{abstract}

Leny Sato - Em primeiro lugar, eu queria agradecer a todos por estarem dedicando um tempo precioso da agenda para essa entrevista. O objetivo dessa entrevista é trazer ao público a história de um órgão sindical, o DIESAT. Até hoje, quando participo de eventos, mesas-redondas - muito embora faça muito tempo que eu tenha saído do DIESAT -, eu sempre me refiro a alguma situação, a algum trabalho que eu desenvolvi nesse órgão. Isto

\footnotetext{
${ }^{1}$ Médico, doutor em Saúde Pública pela Faculdade de Saúde Pública da Universidade de São Paulo, ex-professor colaborador da Faculdade de Saúde Pública (USP), assessor sindical na área de saúde, diretor do Hospital Municipal Dr. Arthur Ribeiro de Sabóia (SP), organizador do livro De que adoecem e morrem os trabalhadores. São Paulo: DIESAT/IMESP, 1984.

${ }^{2}$ Médico sanitarista e do trabalho, doutor em Medicina, área de Saúde Coletiva pela Faculdade de Ciências Médicas da Unicamp, professor da Universidade Federal de São Paulo - Escola Paulista de Medicina (Unifesp-EPM), organizador do livro De que adoecem e morrem os trabalhadores. São Paulo: DIESAT/IMESP, 1984.

${ }^{3}$ Diretor do Sindicato dos Trabalhadores Metalúrgicos de Osasco e Região e ex-diretor do DIESAT.

${ }^{4}$ Diretor do Sindicato dos Trabalhadores em Empresas de Processamento de Dados de São Paulo e diretor financeiro do DIESAT.

${ }^{5}$ Endereço: Rua Tamandaré, 348, 2o andar, São Paulo, SP, CEP: 01525-000. Telefax: (11) 3399-5673, www.diesat.org.br, diesat@diesat.org.br

${ }^{6}$ O DIESAT é dirigido por um colegiado, atualmente composto pelos sindicalistas: Pérsio Dutra "Peninha", Osvaldo Bezerra "Pipoka", Gilberto Almazan, Otávio dos Santos "Ravengar", Ester Lia Gobi Teixeira, Benedito Pedro Gomes, Belmiro Aparecido Moreira e Sérgio Roque.

${ }^{7}$ Outras informações sobre esse tema: a) Sato, L. (1991). A psicologia e a saúde do trabalhador na área sindical. In F. C. B. Campos (Org.). Psicologia e Saúde - repensando práticas. São Paulo: Hucitec. b) Sato, L. (1999). Entrevista com Leny Sato. Psicologia ES Sociedade. 11(2)-9-22.
} 
porque o DIESAT foi, para mim, um importante espaço para conhecer a realidade do "chão de fábrica" e para desenvolver pesquisas e atividades de formação sindical. Cada um de vocês poderia falar do momento em que houve uma articulação de técnicos (médicos, advogados e outros profissionais) e de sindicalistas para criar o DIESAT. Eu acho que o DIESAT fala também de um determinado momento da organização sindical no Brasil, principalmente a dos trabalhadores urbanos no Estado de São Paulo.

Herval Pina Ribeiro - Eu acho que além de construir, reconstruir a história do DIESAT, obviamente a intenção é interpretar essa história: quando surge e por que surge. O Clemente, que é uma pessoa muito cuidadosa, trouxe uma revista do DIESAT, o Gibi dos Trabalhadores, que de certo modo traduz como é que essa instituição nasceu, né? E que foi a partir de uma demanda originada dos trabalhadores que adoeciam de silicose; aliás a história da doença do trabalho sempre começa pelas pessoas que trabalham com mineração ou que trabalham com pedra e, justamente, nós também vemos isso nos "Anos de Chumbo" quando os trabalhadores demandavam muito provas de função pulmonar na Santa Casa que era o único centro que realizava perícias para o INPS ${ }^{8}$. Eu me lembro que o Ercílio Boriero - que era presidente do Sindicato dos Ceramistas de Jundiaí e da Federação dos Trabalhadores em Cerâmica - levava pelas mãos os trabalhadores para fazerem prova de função pulmonar, por que praticamente a única doença reconhecida pela Previdência Social como uma doença do trabalho era a silicose. E esse contato com os sindicatos conduziu a uma proposta de reunir os sindicatos de ceramistas e depois os sindicatos de uma maneira geral para começar a discutir como fazer para prevenir essa doença. Então, essas questões nasceram a partir daí, em um momento em que a clandestinidade do movimento sindical era absoluta, mas já se vislumbrava um período de abertura, de reorganização do movimento sindical.

Leny - Você se lembra em que ano começa essa solicitação dos ceramistas?

Herval - Essa solicitação muito freqüente surge no final dos anos 60 mas ela vai crescendo efetivamente nos anos 70 e era feito na Santa Casa de Misericórdia de São Paulo, onde nós trabalhávamos. O Diogo Pupo Nogueira era professor dessa área e depois eu também comecei a receber os trabalhadores e os sindicatos. Eu era professor da Faculdade de Ciências Médicas da Santa Casa e recebia essa demanda... Essa convivência com os trabalhadores foi crescendo e ampliando com os outros sindicatos. Quando o Movimento Renovação Médica ${ }^{9}$ tomou o Sindicato dos Médicos lá pelos anos de 1978, as reuniões preliminares para organizar o DIESAT - que não tinha esse nome, esse nome é herdado do DIEESE $^{10}$, né, porque na verdade é irmão do DIEESE - passaram a ser realizadas no Sindicato dos Médicos, aí já tendo uma interface forte com o movimento sindical. Desde o início, aquelas pessoas que se agregaram que eram médicos, que pertenciam ou não à diretoria do sindicato, tinham a perfeita consciência de que um órgão dessa natureza precisaria estar alicerçado no movimento sindical; aí começou a se aproximar do Sindicato dos Metalúrgicos de Osasco, do de São Paulo, um pouco dos Metalúrgicos do ABC, dos sindicatos de vidreiros, dos ceramistas, dos bancários e o movimento foi crescendo, organizou-se primeiro uma comissão. Eu me lembro que o primeiro secretário-geral dessa comissão foi o Clemiltre, que era secretário geral do Sindicato dos Metalúrgicos de São Paulo, uma pessoa aliás, belíssima, em termos de integridade e de fraternidade muito forte.

Francisco Antonio de Castro Lacaz - Ele faleceu?

Herval - Faleceu. E era uma pessoa importante. Depois é que se "bateu o martelo" para a criação do DIESAT.

\footnotetext{
${ }^{8}$ Instituto Nacional de Previdência Social.

${ }^{9}$ Foi um movimento político nacional dos médicos assalariados para disputar as diretorias dos sindicatos de médicos, as quais encontravam-se ocupadas por representantes das empresas médicas.

${ }^{10}$ Departamento Intersindical de Estatística e Estudos Sócio-Econômicos.
} 
Leny - E aí, Herval, foram muitas reuniões nesse início para discutir a necessidade da criação de um órgão que tivesse esta característica, que ao final tomou forma?

Herval - É, na verdade, nós seguimos muito os passos do DIEESE e a nossa primeira proposta foi de que essa preocupação com a Saúde do Trabalhador fosse incorporada ao próprio DIEESE, como uma linha de pesquisa do DIEESE. E conversando com os diretores do DIEESE na época, eles acharam que era mais conveniente realmente ter um órgão separado, embora nós nos abrigássemos no mesmo espaço, que era o Sindicato dos Marceneiros de São Paulo. Então o DIESAT nasce como órgão autônomo, junto ao DIEESE. Nós partilhávamos o mesmo ambiente e estávamos alocados no mesmo sindicato. E ele foi crescendo muito com o movimento sindical e com o movimento de redemocratização do país. $\mathrm{O}$ momento era muito oportuno porque se passava para uma liberdade sindical maior e uma organização forte do movimento sindical e essa questão, que era nova enquanto questão coletiva para os trabalhadores, ganhou um vulto muito importante. Esses são os passos gerais, o início que eu me lembro, da criação do órgão, ou seja, ele nasce muito preso à realidade; um processo de uma realidade de industrialização rápida do país, em 1976 foi o ano recorde de acidentes de trabalho. Ele nasce também no declínio da ditadura militar e da ascensão do movimento sindical...

Lacaz - Greves, né?

Herval - Greves... e num processo de redemocratização do país; ou seja, as raízes dos sindicatos é o sofrimento dos trabalhadores e o desejo de liberdade dos trabalhadores e da necessidade.

Leny - Você falou do Movimento de Renovação Médica. Então, na verdade, o grupo de técnicos que participou daquele momento da discussão inicial, era formado, basicamente, de médicos que participaram desse Movimento.

Herval - Vamos dar "nome aos bois". Quer dizer, o movimento sindical que participou do DIESAT de início não era um movimento de esquerda, mas os médicos que freqüentaram o DIESAT eram todos de esquerda. Ou seja, havia a confluência de uma posição ideológica dos intelectuais que se aproximaram do DIESAT, enquanto que, do lado sindical, havia uma demanda concreta para realmente trabalhar essa questão de um modo coletivo. Então, houve a confluência dessa necessidade intrínseca dos trabalhadores e também com essa visão de que a questão do trabalho e das doenças do trabalho eram muito importantes do ponto de vista ideológico.

Leny - E nesse momento, falando do técnicos que participaram, estava você, o Lacaz...

Herval - É, o Lacaz pode me corrigir se eu estiver enganado, estava o Lacaz, o Primo [Alfredo] Brandimiller, a Tereza Mitsunaga [Kulezka], todos médicos.

Lacaz - Tinha o Rebouças [Antonio José de Arruda Rebouças] e o Aníbal [Fernandes], advogados.

Leny - Você chegou a falar, Herval, dos médicos e dos advogados que participaram desse início, falou de alguns sindicatos que estavam também nessa articulação inicial...

Herval - Tem o Sindicato dos Marceneiros que teve um grande papel, um sindicato que dava toda a infra-estrutura.

Lacaz - O Lazinho, dos Marceneiros.

Herval - O Sindicato dos Metalúrgicos de Santos, o Uriel [Vilas Boas] era o diretor...

Lacaz - Porque teve a estratégia das SEMSATs (Semanas de Saúde do Trabalhador), né... 
Leny - Eu imaginei que o Clemente pudesse falar um pouco da participação dos sindicatos. Aqui no Gibi dos Trabalhadores ${ }^{11}$ tem a lista dos sindicatos que participaram da Primeira SEMSAT.

Herval - Ah, e tem os artistas também que participaram. O Laerte ${ }^{12}$ foi, inclusive, quem... porque nós fizemos o roteiro da revista e o Laerte foi quem fez os quadrinhos e termina justamente dizendo que a solução é o DIESAT, né?

Leny - Esta revista, o Gibi dos Trabalhadores, de 1979, número 1...

Lacaz - É da Primeira SEMSAT, sobre as Poeiras...

Leny - Então, nesse momento, o DIESAT não existia.

Carlos Aparício Clemente - Não, vem depois...

Lacaz - O DIESAT é criado em 1980, né?

Clemente - É, agosto de 1980.

Lacaz - A CISAT (Comissão Intersindical de Saúde do Trabalhador) que organizou as SEMSATs , duas SEMSATs. A primeira sobre Poeiras em 1979 e a outra sobre...

Herval - $O$ interessante é que a estratégia adotada foi a de realizar as discussões simultaneamente, em várias cidades... haja fôlego, né?

Lacaz - Eu me lembro que a primeira reunião orgânica mesmo que teve - porque essa discussão já vinha de 1978, a gente fazia algumas reuniões para levantar pontos, questões de interesses - mas a primeira reunião foi no Sindicato dos Médicos, se não me engano, foi em 7 de janeiro de 1979. Ali estavam sindicalistas, médicos, e surgiu a idéia - se não me engano, partiu até do presidente do Sindicato dos Bancários - de criar o "DIEESE da Saúde", porque a referência era o DIEESE. Então o primeiro nome que surgiu foi o "DIEESE da Saúde" e aí um dos técnicos que estava lá, sugeriu a organização das SEMSATs como estratégia para ir aglutinando forças e tal, e é isso que o Herval falou: realizar reuniões em vários locais durante uma semana, para as quais o grupo técnico preparava um documento de base para a discussão e depois fazia uma reunião final, que foi em São Paulo. Duas delas foram em São Paulo. E era uma discussão interessante porque cada categoria de trabalhadores trazia a sua vivência daquele problema que estava em pauta na discussão e procurava contribuir para tirar recomendações e sugestões num documento final que envolvia o aspecto técnico e também as decisões e recomendações políticas.

Leny - Os temas eleitos, como eram definidos?

Lacaz - Eram originários dessa demanda que surgia do movimento sindical. Os Ceramistas de Jundiaí...

Herval - Aliás, o conhecimento nessa área percorre sempre esse trajeto. São situações muito objetivas onde a materialização da causa é perceptível. É bom salientar isso porque essa percepção causal, essa relação causal estreita, ela está assentada na própria raiz da Medicina do Trabalho. Então, só é doença do trabalho aquela coisa que é perceptível e materializada, então, sílica e silicose são coisas que ficam muito próximas. É diferente de hoje: as doenças do trabalho não estão relacionadas a coisas tão materiais assim. E isso vai mudando a trajetória. O próprio DIESAT e as SEMSATs traduzem essa mudança do

\footnotetext{
${ }^{11}$ Material publicado em setembro de 1979 com o intuito de divulgar o material produzido para subsidiar a discussão da Primeira SEMSAT que tratou das poeiras e doenças pulmonares. Apresentado na forma de um gibi, o texto foi elaborado pela equipe técnica da CISAT (Comissão Intersindical de Saúde do Trabalhador) e a criação e a arte final ficaram a cargo de Fausto e Laerte. Esse material foi subscrito por 49 sindicatos e 6 federações de trabalhadores, os quais promoveram essa I SEMSAT e apresenta as conclusões e recomendações elaboradas sobre o tema.

${ }^{12}$ Atualmente cartunista da Folha de São Paulo.
} 
desenvolvimento industrial e esse processo que hoje nós estamos vivendo de reestruturação produtiva.

Sônia ${ }^{13}$ - O Lacaz falou e o Herval também: era muito mais material estabelecer essa causalidade. Hoje a gente lida com aspectos muito mais nas entrelinhas, como a questão do burnout, a questão do stress e eu ia até te perguntar quais eram essas relações objetivas, quais eram os grandes motes que surgiam?

Lacaz - Não sei se o Clemente vai lembrar de todos os temas das SEMSATs, mas as primeiras foram: as poeiras e as doenças pulmonares; depois os agentes físicos (ruído, calor, vibração, radiação), aquela coisa bem palpável, que você mede, quantifica; depois discutiuse a saúde da mulher e do menor, para a qual o DIEESE colaborou elaborando material também; depois a saúde do trabalhador da área rural e fomos para várias cidades no interior (agrotóxicos, acidentes com máquinas), acho que foi a V SEMSAT; depois eu me lembro que a gente discutiu alguma coisa relacionada à previdência social (incapacidades e o papel da previdência social, da reabilitação, da volta ao trabalho, essa lógica de voltar ao trabalho não estando recuperado) e acho que chegou um momento em que estávamos preocupados com a questão do processo constituinte ${ }^{14}$; há uma SEMSAT também sobre agentes químicos. Depois nós tivemos uma sobre novas tecnologias; naquela época estávamos antenados numa discussão que surgiu um tempo depois na academia. E tivemos uma discussão importante que foi discutir a questão da saúde do trabalhador na constituinte. Então foi-se alterando ao longo da trajetória e incorporando isso que o Herval falou: de um momento em que se discutia coisas mais palpáveis, de um nexo muito claro entre condições de trabalho e saúde para essas relações mais complexas mediadas por várias situações que não essa da unicausalidade, da visão mais tradicional da Medicina do Trabalho e tivemos influência da formulação dos italianos, do Modelo Operário Italiano ${ }^{15}$; da Asa Cristina Laurell ${ }^{16}$ que é uma professora da Universidade Autônoma do México, que produziu muitos livros sobre essas relações entre Trabalho e Saúde e que adota uma visão marxista, a qual deu uma certa posição que caracterizou esse grupo. Eu me lembro, inclusive, quando o DIESAT publicou o De que adoecem e morrem os trabalhadores, em $1984^{17}$, esse livro foi uma coisa marcante, porque não se tinha muitos livros nessa área e ele foi, inclusive, adotado em algumas universidades, inclusive em programas de pós-graduação.

Herval - Eu gostaria de salientar que nós todos aqui, inclusive a Leny, porque a Leny entrou no DIESAT em...

Leny - Fins de 1984. Eu participei daquela pesquisa dos bancários ${ }^{18}$.

Herval - Nenhum de nós pertencia à universidade. Na verdade, como o que existia na universidade era a Medicina Ocupacional, a intenção era a de construir um contradiscurso ${ }^{19}$ à universidade; ou seja, entendo que o conhecimento não se constrói só na universidade e precisaria ter um pensamento que, de fora, pudesse, inclusive, influenciar a universidade e essa era a razão, porque também se tinha consciência de que naquela ocasião a universidade

\footnotetext{
${ }^{13}$ Sônia Maria Campos Pittigriane Ferreira, psicóloga do Hospital Municipal Dr. Arthur Ribeiro de Sabóia (local no qual a entrevista foi realizada), participou da entrevista.

${ }^{14}$ Processo Nacional Constituinte que culminou na promulgação da Constituição Federal em 1988.

${ }^{15}$ Ver a esse respeito Oddone, I., Marri, G., Glória, S., Briante, G., Chiatella, M. \& Re, A. (1986). Ambiente de Trabalho - a luta dos trabalhadores pela saúde. São Paulo: Hucitec.

${ }^{16}$ Dentre outros trabalhos, ver: Laurell, A. C. \& Noriega, M. (1989). Processo de produção e Saúde - Trabalho e Desgaste Operário. São Paulo: Hucitec.

${ }^{17}$ Editado em São Paulo, por DIESAT/IMESP.

${ }^{18}$ Seligmann-Silva, E., Delia, A. A. \& Sato, L. (1985). Trabalho e Saúde Mental dos Bancários. São Paulo: DIESAT.

${ }^{19}$ A respeito da distinção entre Saúde do Trabalhor e Saúde Ocupacional/Medicina do Trabalho, ver Lacaz, F. A C. (1996). Saúde do Trabalhador: um estudo sobre as formações discursivas da academia, dos serviços e do movimento sindical. Tese de doutorado. Departamento de Medicina Preventiva e Social da Faculdade de Ciências Médicas da Unicamp.
} 
estava fechada para incorporar questões para um pensar diferente do pensar tradicional, particularmente nessa área. Então, nós estávamos assumindo a situação de que éramos excluídos. Essa era uma situação muito clara para nós.

Leny - E, Clemente, você participou desde o começo pelo Sindicato dos Metalúrgicos de Osasco. O que motivava os sindicatos a criarem um órgão sindical que lidasse com as questões da saúde?

Herval - Quantos anos você tinha quando começou a participar?

Clemente - Comecei a participar dessa articulação quando tinha 23 anos de idade... Uma coisa que eu lembro é que essa articulação era uma intersindical e depois foi dar a idéia de criar um órgão intersindical. As discussões começavam... nós não tínhamos centrais sindicais na época... A idéia de Saúde do Trabalhador na época... Aliás, não se tinha a idéia de Saúde do Trabalhador, tinha-se a idéia de atendimento médico, a visão assistencial; a prática dos serviços médicos nas empresas que tinham médico do trabalho, nas poucas empresas, o trabalho do médico era ficar no consultório, dificilmente ia ao local de trabalho, se bem que passados esses anos todos a gente vê que não mudou... E, de repente, essa proposta dessa reunião no Sindicato dos Médicos, acho que foi legal porque a gente via no sindicato, numa parte do Sindicato dos Médicos, uma conduta diferente daquele médico que a gente conhecia. Isso ajudou bastante essa aproximação... Eu me lembro que o Herval dizia que era necessário que o saber médico conhecesse, se misturasse com o conhecimento dos trabalhadores, compreendendo o que ocorria com os trabalhadores. Eu me lembro que se falava muito isso naquelas reuniões: que era a partir do conhecimento das pessoas, do que elas enfrentavam no trabalho que se poderia mudar a forma dessas relações. Talvez o que o sindicato dos médicos falava naquela época, era o que Ramazzini ${ }^{20}$ falasse há alguns séculos. Então, mas o sindicato dos médicos "sacou" aquilo, e hoje, na Conferência de Saúde realizada no município de Osasco semana passada, essa foi a tônica central. Mas o seguinte, para nós, os sindicatos de trabalhadores, foi importante aquela aproximação? Com certeza absoluta! Foi, porque a gente não conseguia pensar diferente também, né? A gente estava lá atuando em relação à CIPA $^{21}$ : "vamos fazer a eleição de uma CIPA". A gente não conseguia pensar de uma forma mais ampla. E quando nós fizemos a primeira Semana de Saúde do Trabalhador, que foi em maio de 1979, eu acho que ali começa a ter um movimento muito legal, que foi sobre "Silicose e doenças pulmonares provocadas por poeira", se privilegiou o quê? Organizar um documento técnico e com esse documento técnico, aí saíamos à caça de sindicatos que estivessem dispostos a organizar uma reunião no sindicato. E isso então a gente viu, em relação à silicose, que tinha muitos sindicatos altamente organizados, sindicatos do interior do estado, como o dos ceramistas de Jundiaí, que é o exemplo maior, tanto é que o final da primeira SEMSAT, nós fizemos dois finais: um aqui em São Paulo e outro em Jundiaí.

Lacaz - Em Pedreira...

Herval - E tem o filme, né: O pó nosso de cada dia²2. E ele vem depois, em 1979-1980.

Clemente - Mas aquilo foi importante porque mesmo que brigássemos entre nós, fizéssemos uma discussão entre pesquisadores, médicos, dirigentes sindicais não médicos, nós fomos aprendendo a conviver. Naquela época nós éramos uma comissão, não tínhamos recurso, era a vontade das pessoas, era a vontade dos sindicatos e das pessoas mesmo... sai prá cá, sai prá lá... Não existia nada, você tinha um grupo estudando, produzindo documentos sobre o tema e, de repente, encontrar quem estava a fim de trabalhar isso prá alastrar a discussão. Eu acho que a idéia daquele momento era essa, então eu me sentia um soldado nessa

${ }^{20}$ Ramazzini, B. (1700/2000). As doenças dos trabalhadores. São Paulo: Fundacentro.

${ }^{21}$ Comissão Interna de Prevenção de Acidentes.

${ }^{22}$ Esse filme trata das doenças pulmonares decorrentes da exposição à poeira e foi realizado pela OCA Cinematográfica. 
discussão, como eu me sinto até hoje... Em relação aos meios de comunicação, eles sempre sabotaram as discussões dos trabalhadores. A gente imaginava: "Ah, a imprensa vai cobrir". Nunca cobriu! Só eventualmente. Não havia interesse da mídia de tratar o tema. As universidades, acho que algumas que chamaram essas reuniões eu tive a oportunidade de me reunir em alguns locais, vários de nós aqui, mas era por curiosidade, nós íamos a vários estados, mas era por curiosidade: "Ah, o que está acontecendo em São Paulo?" Era curiosidade, e às vezes quando a universidade chamava a discussão, aí então a imprensa ia cobrir porque a universidade havia chamado. Quando era uma organização dos sindicatos aí era muito pequena a cobertura da imprensa.

Lacaz - Quando íamos à reunião da SBPC, a Sociedade Brasileira para o Progresso da Ciência.

Clemente - SBPC, mas era curiosidade!

Leny - Como algo exótico.

Clemente-É... é, exatamente!

Herval - Onde já se viu sindicalista e quem não é professor produzir conhecimento?!

Clemente - E aí, quando saiu a Primeira SEMSAT, quando saiu esse gibi, acho que talvez seja uma obra-prima que o Laerte desenvolveu, porque ele conseguiu traduzir, lá no ano de 79, uma coisa que era "Doenças Pulmonares" de uma maneira que qualquer pessoa entendia. Hoje a gente não consegue fazer isso. O Laerte teve essa sensibilidade para traduzir no desenho, no cartoon etc... Foi uma coisa muito legal que nós não conseguimos fazer na Segunda SEMSAT, quer dizer, os sindicatos não tiveram pernas para... é uma crítica que eu faço àquele momento. A gente era muito bom de idéias. Na hora de pôr dinheiro do bolso, os sindicatos não põem dinheiro! $O$ falecido Junqueira, da $\mathrm{ABPA}^{23}$ que imprimiu.

Herval - Eles imprimiram, o Laerte fez tudo isso e não cobrou um tostão; ninguém ganhava. Porque é bom salientar que essa construção de ter pesquisador no movimento sindical, a nossa intenção era de que os sindicatos pudessem sustentar esses pesquisadores e formar outros. A idéia de ter uma universidade aberta; ou seja, uma entidade que nessa área cobrisse uma forma de conhecimento diferente. Era um projeto ambicioso para formar pessoas que pensassem diferente. Nunca conseguimos isso. A tentativa de ter financiamento nessa área foi atropelada, e era um recurso da Itália, você já estava dentro do DIESAT, Leny, era um recurso da $\mathrm{CGIL}^{24}$, uma central sindical italiana, no final dos anos 80 . Eu me lembro que as iniciativas foram feitas junto à CGIL, esse dinheiro estava carimbado. A Edith Seligmann ${ }^{25}$ teve uma participação importante antes, com contatos, né... e esses 3 milhões de dólares foram atravessados pela CUT e pelo PT e o dinheiro foi prá CUT que construiu o INST $^{26}$ e que consumiu o dinheiro todo. É bom que a gente diga isso com todas as letras porque a expectativa que nós tínhamos na época era outra. Evidentemente que falo da CUT enquanto organização sindical, e não de pessoas. A CUT na época e as outras centrais sindicais já tinham uma outra visão sobre sindicalismo. Não seria mais o DIEESE, como também não seria mais o DIESAT, então a própria CUT teria o seu DIEESE e o seu DIESAT. A história mostrou que eles estavam errados. O DIEESE continua aí e o DIESAT, embora com muitas dificuldades, está aí também, mesmo sem os 3 milhões de dólares.

\footnotetext{
${ }^{23}$ Trata-se de Joaquim Augusto Junqueira, então superintendente da Associação Brasileira de Prevenção de Acidentes.

${ }^{24}$ Confederazione Generale Italiana del Lavoro.

${ }^{25}$ Edith Seligmann-Silva, ex-colaboradora do DIESAT, é psiquiatra, foi professora da Faculdade de Medicina da Universidade de São Paulo, atualmente professora da Escola de Administração de Empresas de São Paulo - Fundação Getúlio Vargas, autora, dentre outros trabalho, de Saúde mental no trabalho dominado, publicado em 1994 em São Paulo pela Cortez Editora/UFRJ Editora.

${ }^{26}$ Instituto Nacional de Saúde no Trabalho.
} 
Lacaz - A CGIL procurou incialmente o DIEESE que era o órgão intersindical de referência e o Barelli ${ }^{27}$, na época coordenador técnico do DIEESE, levou os sindicalistas italianos até o DIESAT, que, inclusive funcionavam no mesmo prédio, no Sindicato dos Marceneiros de São Paulo. Desse contato surgiu a possibilidade de elaborar um projeto que continha vários aspectos, dentre eles, de formação, de pesquisa, de banco de dados e de publicações. Esse projeto, se concretizado, daria autonomia para o DIESAT e talvez a história tivesse sido diferente.

Clemente - Então, eu me lembro que naquele momento ainda, em 79, da Primeira para a Segunda SEMSAT. A primeira discussão foi legal, vamos partir agora prá um outra discussão: era os agentes físicos no trabalho (ruído e outros). Aí se percebeu assim, onde seria legal discutir esse tema.

Lacaz - Era um tema mais abrangente, pegaria todas as categorias de trabalhadores.

Clemente - Pegava indústria têxtil, pegava... Aí saímos mapeando para ver onde dava prá fazer essa discussão, em quais categorias e sindicatos. O setor metalúrgico é um público alvo. E uma coisa que eu não esqueço até hoje, foi muito legal isso, nós saímos daqui e fomos em um sindicato em São José dos Campos, e fomos prá vários sindicatos, prá mostrar a idéia, tal, prá mostrar o que era a SEMSAT: os sindicatos da região convocam a reunião, a gente produz um documento, barateia ao máximo todos os gastos e depois, a reunião instalada, vai ajudar no encaminhamento, mas a responsabilidade de organização é do sindicato local... Eu não me esqueço de um dirigente sindical que falou prá nós: "Eu autorizo vocês a fazerem a entrega do boletim nas portas das minhas fábricas". Aí o Herval ficou doido e falou: "Não, mas não é isso!" [risos]

Leny - Ele entendeu tudo, né? [risos]

Clemente - Como se ele fosse dono das fábricas, das portas da fábricas da cidade! (risos) "Eu autorizo vocês!"... Aí nós falamos: "Não, vocês vão convocar, a gente vai vir. Vocês escolhem o melhor dia". Depois que ele entendeu, aí ele teve uma saída: tem um determinado sábado que o pessoal fazia a entrega do cheque da bolsa de estudos da PEB (Programa Especial da Bolsa de Estudos). Aí ele falou: "No dia em que a gente for fazer a entrega da bolsa de estudos, aí vocês vêm e fazem uma palavra com o pessoal aî". [risos]

[Todos riem]

Clemente - Isso em São José dos Campos e isso em Osasco também. Em Osasco o pessoal é amigão da gente. Em Osasco, como o tema era ruído, nós descobrimos que tinha uma tese, acho que era de mestrado, da Faculdade de Saúde Pública, que era do médico de uma empresa... [risos] ... hoje ele é amissíssimo da gente... Na época, em setenta, eu fiz contato com ele: "A gente vai ter uma discussão assim, sobre ruído, o senhor participa lá com a gente?". Ele falou: "Olha, eu fiz a tese, a tese é para o meu mestrado e eu não vou ficar debatendo a tese em sindicato"... Hoje ele saiu da empresa e é um dos batalhadores aí. Mas na época, talvez devido à repressão violenta dentro da empresa, aí talvez o fato de um médico da empresa ir ao sindicato, não sei o quê poderia acontecer com ele, não sei o quê passou na cabeça dele, e a gente não se conhecia direito. Talvez até, esse momento, era agosto de 79... Agora, do ponto de vista de organização, o que eu vi assim nas semanas de saúde que depois deram origem à criação do DIESAT... Para nós, lá no sindicato foi muito legal, a Primeira, a Segunda Semana de Saúde do Trabalhador. Para nós lá no sindicato também era nova essa discussão. Tinha pessoas na direção do sindicato, eram pessoas que estavam chegando ali, mas eram dirigentes que entendiam que essa discussão não era discussão para sindicatos: "Olha, Saúde do Trabalhador, isso é coisa de governantes, coisa de médico". Tanto é que até se pensava, o nosso presidente da época, o Henos Amorina, que até chegou a comentar de

${ }^{27}$ Walter Barelli, economista que foi por vários anos coordenador técnico do DIEESE. 
convidar o presidente do sindicato dos médicos, o Agrimeron prá ser médico do trabalho do sindicato. "Se eu ponho ele aqui, ele vem prá cá e..." Mas não era essa a proposta e nós também evoluímos nesse debate. Esse tema, a Saúde do Trabalhador, eu tive uma sorte de esse tema ter crescido lá no sindicato de Osasco, e a gente ia fazer a Terceira SEMSAT em fevereiro de 1980, não aconteceu, aí nós fizemos um encontro lá... Um encontro que no fim teve que virar Ciclo de Debates sobre Saúde do Trabalho dos Sindicato dos Metalúrgicos de Osasco e Região, em julho, pela grande quantidade de gente. E quinta-feira agora nós fizemos a de número 24, o Peninha esteve lá.

Herval - Como é que os sindicatos poderiam, em parte abrigar alguns técnicos. Uma das maneiras era a de que alguns sindicatos que apostavam um pouco mais poderiam pagar os técnicos que os assessoravam e pagavam o técnico para trabalhar para ele e algumas horas eram cedidas para trabalhar para o DIESAT, que era o modelo que o DIEESE usava. Isso aconteceu, por exemplo, no Sindicatos dos Químicos do ABC, comigo e com o Lacaz. Nós tínhamos conhecimento de que o fato de nós estarmos debilitados economicamente impedia que nós elaborássemos pesquisa e tínhamos a exata consciência de que era impossível fazer pesquisa por causa da ausência de recurso. Então, a aposta foi de reproduzir o conhecimento e me parece que nesse aspecto foi uma coisa muito interessante por que nós produzimos um farto material

Lacaz - Os boletins ${ }^{28}$ do DIESAT.

Herval - Artigos, comunicações em congressos e dois livros que marcaram época, particularmente o primeiro que é o De que adoecem e morrem os trabalhadores de 1984 e o Insalubridade - morte lenta no trabalho, de 1989, além desse filme O pó nosso de cada dia, que é um marco também porque filma-se tudo e tem uma particularidade: não somente o discurso é do trabalhador como a narrativa é de um sindicalista.

Lacaz - É do Hercílio, né?

Herval - É, muito interessante, muito bonito e que foi a custo zero para os sindicatos porque foi uma empresa de amigos que financiou.

Lacaz - Eu me lembro que nós fizemos uma discussão desse filme no MIS (Museu de Imagem e do Som), com o Ricardo Bruno ${ }^{29} \ldots$

Herval - Com o Bernardet, com o Jean-Claude Bernardet, que é um crítico de cinema. Esse filme está em Cuba também, alguém levou prá lá. A verdade é o seguinte: a pobreza da produção científica nessa área era de tal ordem que o DIESAT fez um contradiscurso forte nessa área. Felizmente, hoje muitos dos técnicos do DIESAT, da época, são professores hoje na universidade, então está abrindo-se um pouco mais para esse discurso, que nunca foi, diga-se de passagem, hegemônico.

Lacaz - Se bem que nessa época também fizemos as pesquisas, ainda que não fosse o principal, a dos bancários, a dos metroviários ${ }^{30}$, em 1985, então já estudando essa questão da saúde mental, as mudanças do trabalho no setor bancário, já pegando essas questões das mudanças do setor bancário, a reestruturação produtiva; a dos metroviários, estudando também a questão dos turnos alternados. No caso dos metroviários, a demanda era inclusive para negociar essas questões na campanha salarial. Mudaram a organização dos turnos mas isso não teve continuidade. Acho que essa é uma crítica também que a gente deve fazer

\footnotetext{
${ }^{28} \mathrm{O}$ Boletim Trabalho $\mathcal{E}$ Saúde trata de temas diversos de interesse dos sindicatos de trabalhadores, desde os relacionados às condições/organização de trabalho e saúde, passando pelos relativos às políticas públicas de trabalho, saúde e previdência social até os referentes à atuação sindical em Saúde do Trabalhador.

${ }^{29}$ Foi professor do Departamento de Medicina Preventiva da Faculdade de Medicina da Universidade de São Paulo.

${ }^{30}$ Seligmann-Silva, E.; Delia, A. A. \& Sato, L. (1986). A saúde na área operativa do Metrô de São Paulo. São Paulo, DIESAT, 319p., mímeo.
} 
porque mudou a direção do sindicato, o estudo ficou como algo da diretoria anterior... a coisa da política brasileira.

Clemente - A principal obra do movimento sindical é essa... geral, heim... [risos]

Leny - É, essas duas pesquisas foram coordenadas pela Edith Seligmann [Silva], e a Agda [Aparecida] Delia, que é socióloga, e eu participamos também pelo DIESAT.

Lacaz - E tivemos aquela pesquisa com os aeronautas que era sobre aquela questão dos vôos de longa duração.

Herval - uma tese muito interessante, porque os aeronautas, nos momentos de descanso fora do lar, estavam submetidos às mesmas regras existentes nos momentos de trabalho, num quarto partilhado.

Lacaz - Então estava dividindo o mesmo quarto o comandante e o sub-comandante, por exemplo, e aí... criavam-se situações muito curiosas que foram narradas.

Leny - É, porque você se mantém o tempo todo em público, o tempo todo "em trabalho".

Herval - uma das pessoas que estava nessa pesquisa foi o Wanderley Codo, psicólogo.

Leny - O Francisco Drummond, que é psiquiatra.

Herval - A inclusão de alguns técnicos e pesquisadores nos próprios sindicatos e a partir daí também teve algumas pesquisas nessa área. Surgiram algumas teses nessa área, nos anos $80 \mathrm{e}$ sobretudo nos anos 90 surgiram muitas teses nessa área. É o caso da Tereza [Mitsunaga], o seu próprio [Leny Sato].

Lacaz - A Lys [Esther Rocha], médica.

Pérsio Dutra (Peninha) - A dissertação da Lys é de $1989^{31}$, foi com a categoria de processamento de dados, sobre as lesões por esforços repetitivos. Ela começou... e coincide justamente com a época em que foi reconhecida a tenossinovite como doença do trabalho pela Previdência Social.

Lacaz - Pelo Ministro da Previdência na época, o Waldir Pires e Rafael Magalhães que era o presidente do INAMPS.

Leny - uma coisa que eu estava observando é a composição da diretoria do DIESAT. Não sei se é verdade, mas talvez tenha havido um momento em que a composição da diretoria era de sindicatos do setor industrial e depois começa a ter uma composição com sindicatos do setor industrial mas também começa a ter o de serviços, que vai mostrar como os temas relativos à organização do trabalho, à introdução de tecnologia informatizada, no setor bancário, ou no setor de processamento de dados e que começa a ter uma demanda importante. Os bancários começaram a participar da diretoria do DIESAT em 1984.

Peninha - Sim, o Gilberto [Salviano da Silva], o Paulinho.

Lacaz - O Mauri, do Sindicato dos Bancários de Campinas.

Herval - Aí você nota dois fenômenos. O recuo dos sindicatos industriais e o avanço dos sindicatos de serviços com, vamos dizer assim, o recuo de uma categoria que progressivamente está deixando de ser categoria para ser ocupação, que é a dos bancários; quer dizer, o processo de esvaziamento da categoria bancária é um sintoma muito importante disso. Então, você aumentou muito os serviços, mas retirando, inclusive, da categoria bancária. O próprio sindicato da categoria de processamento de dados já é um

\footnotetext{
${ }^{31}$ Rocha. L. E. (1989). Tenossinovite como Doença do Trabalho no Brasil: a atuação dos trabalhadores. Dissertação de Mestrado, Departamento de Medicina Preventiva, Faculdade de Medicina da Universidade de São Paulo São Paulo.
} 
filhote da profissão de bancário.

Peninha - Não, não seria da profissão de bancário. Na realidade, não o sindicato em si, mas a categoria de processamento de dados é originária de uma demanda por serviços terceirizados, por exemplo: cálculo de folha de pagamento, cálculos estruturais que se faziam em bureaux de computação. Isso dá-se com a disseminação do uso do computador no país, e você tinha uma gama grande de empresas que não tinham um recurso suficiente para implantar um parque computacional e como tinha quem tivesse capital para fazer um bureau de serviços para oferecer esse serviço para as empresas. Isso dá-se sem que houvesse uma vontade de tais empresas para terceirizar essas atividades. Os bureaux oferecem seus serviços para empresas que não tinham condições de capital econômico para implantar um parque computacional, na época. O computador era alguma coisa extremamente caro, não era disseminado como hoje. Naquela época havia duas ou três marcas e praticamente não havia computadores vendidos, havia sim computadores alugados. Então são empresas multinacionais que trouxeram o parque para cá, como a IBM. Então tem essa diferença, agora não digo que posteriormente não se tenha usado toda essa terceirização já, não mais tendo como pano de fundo essa restrição econômica para terceirizar.

Leny - E assim, da mesma forma que começa a haver uma participação de sindicatos do setor terciário, hoje participa da diretoria do DIESAT o Sintratel ${ }^{32}$, que é de trabalhadores de telemarketing, que começa a aparecer mais recentemente.

Peninha - E grande parte deles, justamente, sai da categoria de processamento de dados e da categoria bancária.

Leny - E que assim, pensando o DIESAT, eu acho que tem duas leituras: uma é a própria mudança e a criação ou extinção de algumas categorias profissionais e como essas categorias começam a participar do DIESAT e a outra é que elas venham buscar uma outra compreensão para os problemas de saúde do trabalhador, certamente porque começam a aparecer, talvez não novos problemas, necessariamente. Se nós formos ler aquele texto que se chama "A neurose das telefonistas" 33 ali vai-se estabelecer uma relação de causalidade bem direta - da mesma forma que se estabelecem relações de causalidade entre doenças e agentes físicos, químicos e biológicos - começa-se a descrever naquele momento, década de 50, o que eles denominaram síndrome da neurose das telefonistas, e que hoje, para quem trabalha nos serviços de telemarketing, muitas daquelas descrições são vividas ainda hoje pelos trabalhadores. Hoje, muitas daquelas condições de trabalho - até porque muitas das situações não são passíveis de serem compreendidas mediante uma relação de causa-efeito em que você pega a poeira na mão e mostra: "é a poeira que causa isso" - acabam sendo uma situação na qual a relação é muito mais complexa para se estabelecer e para a previdência social a lógica é a a de que "poeira causa silicose", e que não dá mais. Parece que tem aí uma busca, com a vinda desses sindicatos para o DIESAT, para ter outra abordagem sobre os problemas de saúde. Mostra também, a vinda desses sindicatos para o DIESAT, como esses problemas estão disseminados.

Herval - Eu acrescentaria até, Leny, que a crise do DIESAT, o esvaziamento e a retirada de inúmeros sindicatos, é porque a lógica - e veja, não é só dos sindicatos e trabalhadores, mas dos próprios profissionais que trabalham na área - continua pensando na causalidade linear, objetiva e material; ou seja, os médicos não conseguem transcender a questão da causalidade objetiva, linear. Antes eram os germes; no caso da Medicina do Trabalho eram os agentes físicos, químicos, as poeiras, o calor etc. Aí quando você não tem essa materialidade, ele fica perplexo com a LER, com a psicose, doenças como a... isso tanto para os profissionais como para os próprios trabalhadores. É muito difícil você encontrar um

\footnotetext{
${ }^{32}$ Sindicato dos Trabalhadores em Empresas de Telemarketing.

${ }^{33}$ Le Guillant, Roelens, Begoin, Béquart, Hausen\& Lebreton (1956/1984). A neurose das telefonistas. Revista Brasileira de Saúde Ocupacional, 47 (12), 7-11.
} 
sindicato que aposte numa discussão, a não ser que tenha efetivamente, um nível de teorização que permita... O grande desafio para o movimento sindical é realmente se apropriar de um conhecimento que lhe foi expropriado, quer dizer, se os trabalhadores não conseguirem isso eles perdem a batalha...

Leny - E nesse contexto de mudanças do trabalho, a reapropriação desse conhecimento depende de os trabalhadores conseguirem dar voz ao que percebem no corpo. Não é alguém de fora que pode dizer se o trabalhador está ou não com problema de saúde.

Clemente - Agora pensando, passados alguns anos da criação do DIESAT, a gente imaginava, até por estar junto, ali, do DIEESE, a avaliação que nós tínhamos assim, sobre a atuação sindical na questão da saúde e na questão econômica. Enfrentava-se inflação alta naquele momento, mas as questões econômicas eram questões pontuais. A questão da saúde o trabalhador vivia a todo momento, a gente tinha aquele raciocínio e imaginava, que por conta disso, rapidamente, o DIESAT, ao ser conhecido, teríamos, assim, uma avalanche de adesões de sindicatos ao DIESAT, mas isso não ocorreu; mas a gente vivia num momento de crescimento econômico. Então, hoje, passados alguns anos, eu vejo, lá em Osasco, nós temos na base do nosso sindicato, um terço da base que nós tínhamos na época de criação do DIESAT. Há uma queda enorme nos postos de trabalho de uma maneira geral de modo que nós imaginávamos que, uma vez reduzida a questão da inflação, a tendência seria de os sindicatos se aprofundarem mais na questão da saúde, ter mais tempo de trabalhar essas questões. Bem, hoje nós temos um desemprego violento que já começa em meados dos anos 80, não é nos anos 90, é nos anos 80 que já começa uma onda de desemprego.

Peninha - Um complemento: e atinge em cheio uma categoria que o Herval falou que é a categoria dos bancários, que já de cara perde 150 mil postos de trabalho.

Clemente - Sim, e a figura da terceirização, que é uma coisa com a qual não estávamos acostumados, não entendíamos, mas ela vem vindo e uma coisa que o Dr. Herval sempre falava, a questão da organização do trabalho, inclusive dos riscos do trabalho: as grandes corporações vão jogando o trabalho sujo para os países periféricos, vão jogando depois para empresas periféricas, e assim por diante. Nós vivemos isso naquele momento. No momento em que aumentava o conhecimento de algum risco à saúde, as empresas entravam com terceirização, com quarteirização, com a entrada das cooperativas que nós estamos vendo agora, que está destruindo o restinho de emprego com carteira assinada... Tudo isso fez com que o movimento sindical, que já não tinha muita vocação para trabalhar esses temas, hoje, temos uma inflação baixa, mas por outro lado, eu vejo que a maior parte do tempo da vida do sindicalista hoje é correr atrás dessas desgraças em torno do emprego... é a destruição... provavelmente até para manter a própria existência dos sindicatos. O dirigente sindical fica correndo atrás disso! Quantos trabalhadores têm a oportunidade de ficar no mesmo emprego durante um ano? Pouquíssimas pessoas! Então, conhecer o risco ao qual está exposto? Quantos? O dirigente sindical também não tem condições de conhecer as mudanças que ocorrem nas empresas... todo o processo mudou e a pessoa não sabe o quê está ocorrendo.

Peninha - Eu acho que não tenho muito a acrescentar ao que o Clemente já falou, mas eu vejo uma outra coisa além disso. Eu vejo, por exemplo, trabalhadores que têm plena consciência do mal que o trabalho lhe causa - eu estou falando de coisas que se refletem no ambiente psicossocial do trabalho que é a pressão da chefia, aquele medo do desemprego, fazer hora extra sem cobrar, porque tem banco de horas e "vamos nessa porque precisamos vestir a camisa da empresa" - justamente para não perder o emprego se calam; é aquela situação da pessoa estar trabalhando com dor e não ir ao médico porque ele não pode se afastar, porque senão vai ficar sob a mira do capataz e aí é "ir pr'o olho da rua" . É tudo isso aí e que ele, na realidade, não deixa de conhecer, mas ele simplesmente... 
Leny - Faz de conta e...

Peninha - Finge que aquilo não existe para poder sobreviver nesse ambiente.

Leny - E aí vocês acham, nessa situação que vocês descrevem que, na verdade, o desemprego acaba sendo um "fantasma", que é um controle muito forte nesse sentido sobre o trabalhador, "eu calo a boca e eu agüento a barra prá não perder o emprego"?.

Peninha - É, e de sindicato eu, trabalhador, só vou querer saber depois que eu for demitido, porque senão "aqueles malucos lá, vão atrapalhar a minha vida!".

Leny - Mas então, em função desse contexto todo, da dificuldade de conseguir sustentar financeiramente o DIESAT, essas mudanças ocorridas, como relatado pelo Clemente e por você, Peninha, isso tudo tem conduzido a uma dificuldade para o DIESAT conseguir um espaço maior de visibilidade?

Peninha - Isso aí, sem dúvida, é um dos fatores para uma dificuldade maior inclusive de inserção do DIESAT junto às entidades sindicais. Elas tiveram um outro problema nessa década de 90, que foi uma política deliberada de enfraquecimento, de flexibilização das relações de trabalho e, principalmente, de enfraquecimento das entidades representativas dos trabalhadores, o que jogou muitos sindicatos numa situação econômica pavorosa.

Clemente - Isso aconteceu com sindicatos organizados, inclusive.

Peninha - Sim, sindicatos organizados foram atingidos. Sindicatos fortes, com uma tradição, com tradição de luta entraram numa crise violentíssima. Isso daí também ajuda a afastar os sindicatos do DIESAT. Na situação atual, de tudo o que está girando em torno do emprego e da empregabilidade, há uma tendência, por exemplo, de os sindicatos considerarem muito mais importante, nesse momento, o DIEESE do que o DIESAT.

Herval - Que nunca deixou de estar em crise, o DIEESE.

Peninha - Mas, na área de saúde, até porque os dirigentes sindicais , grande parte não se preparou para conhecer as condições de trabalho, os agravos à saúde que o trabalho pode trazer para os trabalhadores de sua base...

Lacaz - Atuar na área de saúde exige um trabalho muito mais contínuo do que atuar na questão salarial.

Peninha - Aqui também a gente tem que colocar uma questão que o Herval já apontou, que é uma mudança na visão das centrais sindicais em relação ao que é um organismo que pensa intersindicalmente a saúde, achando que um órgão de saúde deva servir à política daquela central estritamente... tudo isso ajuda um órgão intersindical a ter dificuldades. $\mathrm{O}$ interessante é que, com tudo isso, subsiste a consciência de que é necessária a existência de uma entidade que produza conhecimento sobre saúde e condições de trabalho e que seja ligado ao ponto de vista dos trabalhadores e que resgate a cultura dos trabalhadores em relação àquilo que seu trabalho lhe cause, tanto em relação à sua saúde, à sua família etc... O DIESAT quase acabou, de uns tempos para cá ele começa a ser solicitado, com a questão da privatização do Seguro de Acidente de Trabalho...

Herval - Que, diga-se de passagem, o documento produzido pelo DIESAT mudou a própria posição das centrais...

Leny - Eu estava lembrando, vendo o livro do DIESAT e ouvindo toda essa discussão sobre a mudança da Previdência Social atualmente em função da Proposta de Emenda Constitucional 40... essa discussão sobre previdência social o DIESAT já tinha feito há muito tempo! São coisas muito antigas e que voltam, e o DIESAT já havia feito: a questão sobre o custeio da previdência, a previdência complementar, a participação do Estado nesse 
custeio, o uso da verba da Previdência para construções de obras etc...e o que a gente observa é que hoje ela tem sido feito de forma bastante desqualificada...

Clemente - A gente observa que em assuntos econômicos e de saúde, a gente vê que o movimento sindical tem buscado parceiros para seus trabalhos, pesquisas, e eu vejo, por exemplo, no caso do amianto, no caso do seguro de acidente de trabalho. Eu vivi alguns momentos, eu fui conselheiro no Conselho Nacional de Saúde e eu via que havia pessoas que achavam que a solução para a Previdência Social era a privatização, pessoas que participavam do Conselho. O Conselho Nacional de Saúde nunca conseguiu entender a questão da Saúde do Trabalhador. Quando tivemos, agora, o anúncio da RENAST, a Rede Nacional de Saúde do Trabalhador, houve posicionamentos de secretários estaduais de saúde contrários a isso. Eles nunca tiveram clareza disso, mas algumas pessoas do movimento sindical, quando assumiram posições-chave em órgãos públicos, utilizaram o seu cargo no setor público, muitas vezes para torpedear discussões que estavam vindo do movimento sindical. Isso eu acompanho com uma nitidez muito grande em relação ao amianto, muito grande! O papel que dirigentes da Fundacentro desempenharam em relação ao amianto, inclusive patrocinando a vinda de gente do exterior prá cá, que defendiam o uso do amianto prá tentar usar a imprensa, os meios de comunicação e sabotar o movimento sindical. Por isso que eu acho que é importante a gente conseguir encontrar meios de desenvolver nossas pesquisas, nós não temos dinheiro, nós precisamos criar meios prá isso. Por exemplo, o DIEESE tem uma pesquisa sobre desemprego na Grande São Paulo, e nesse momento, está em uma discussão sobre o convênio SEADE/DIEESE ${ }^{34}$ que culminou, nesse mês, com a discussão sobre o que é desemprego, que vai definir se a taxa de desemprego é $15 \%$ ou se é 20\%. Então o DIEESE fala: "é 20\%" e o SEADE fala: "não, se o sujeito vendeu bala no semáforo nesse dia e conseguiu recurso, então não é desemprego". Então, isso aí levou a uma ação das centrais sindicais a pressionarem o governador do Estado, e essa reunião ocorreu na semana passada, porque uma metodologia antiga de pesquisa, que era aceita pelas duas partes, de repente, uma das partes - e uma delas era quem colocava recursos (o SEADE) na pesquisa -, queria mudar a metodologia. Para pensar como nós não conseguimos, no DIESAT nos manter, então, como mostra esse caso do DIEESE. Boa parte dos recursos do DIEESE também não é do movimento sindical mas sim de convênios que ele foi fazendo aqui e ali, e de repente, uma crise, um órgão que tem o poder de denunciar o convênio, coloca em risco um órgão, uma estrutura; no caso do DIEESE são 230 funcionários, e hoje se discute a demissão de um terço desses funcionários. E ainda, a maior parte dos recursos é de convênio. Hoje o DIEESE está programando uma ação, assim como nós do DIESAT fizemos, procurar sindicatos para filiação. Então não é só para o DIESAT que o movimento sindical não tem como dar recursos, é para o DIEESE também.

Leny - Tem várias questões que vocês estão falando e que suscitam muitas outras e o aprofundamento de diversas delas. O DIESAT foi criado num momento em que não havia, ainda, as centrais sindicais. Como falou o Peninha, com a criação delas passa a existir uma visão distinta dos sindicatos sobre o papel desses órgãos intersindicais, houve o episódio da possibilidade de o DIESAT ter obtido o recurso da CGIL, mas esse dinheiro acabou migrando para uma central sindical, a CUT, que criou um órgão próprio, o INST, e a gente também não tem visto atividades do INST. Seria interessante que vocês falassem se alguma coisa muda, e como muda, na relação do DIESAT com os sindicatos, com isso.

Herval - Havia alguma expectativa de explorar algumas perspectivas para o DIESAT atualmente, através da idéia de que, mesmo não contando com pesquisadores organicamente, funcionalmente com pesquisadores, entre eles, muitos dos que foram técnicos do DIESAT e que estão na universidade, que contasse organicamente com a

${ }^{34}$ Trata-se de convênio entre a Fundação SEADE (Fundação Sistema Estadual de Análise de Dados) e o DIEESE (Departamento Intersindical de Estatística e Estudos Sócio-Econômicos) que garante, desde 1984, a realização da PED (Pesquisa de Emprego e Desemprego) na região metropolitana de São Paulo, mediante levantamento domiciliar contínuo. 
construção desse discurso contra-hegemônico enquanto estavam ou estão na universidade, eu acho que esta é uma possibilidade grande. A própria questão das relações entre Trabalho e Saúde é maior do que o DIESAT, obviamente. Ela existe, consequentemente, ela deve ser explorada, pesquisada onde se possa fazer pesquisa. Então, a universidade é uma forma e o estreitamento com a universidade é uma possibilidade muito grande. Uma possibilidade disso é com alguma articulação que o DIESAT está fazendo com órgãos internacionais ligados a centrais de trabalhadores, no sentido de viabilizarmos projetos dessa natureza. Ainda que você não possa ter esses técnicos como técnicos do DIESAT, pode-se ajudar a produzir utilizando-se a própria prática dentro da universidade; ou seja, uma das perspectivas para o DIESAT é fortalecer esse elo com a universidade. O que está faltando, realmente, é massa crítica dentro do movimento sindical para tornar viável esse projeto, dentre eles o projeto de revisão do livro De que adoecem e morrem os trabalhadores, que já está formulado mas que parece que o movimento sindical não teve fôlego para dar andamento, porque a predisposição dos pesquisadores existia. Há um contradição da sociedade brasileira que precisa ser olhada mais de perto. Uma delas é a ascensão de um partido de esquerda ao governo. De repente, esse partido de esquerda "chupa" os melhores quadros do movimento sindical para ocupar cargos burocráticos e, obviamente, "amarra" esses quadros a uma agenda que é de governo, mas que não é nem sequer de partido e como o governo é composto por partidos de esquerda e de centro-esquerda, amarra também os partidos. Isso é um complicador porque esvazia o movimento social, isto é um risco que alguns perceberam: quando você atrai as pessoas para o governo, elas ficam silenciosas. Os que criticam ficam ameaçados de serem expulsos do partido. Isso é uma contradição muito séria! É uma questão que passa por qual democracia nós queremos nesse país, não há como escapar. Não se trata de discutir apenas "vamos deixar prá amanhã porque precisamos governar primeiro prá juntar depois". Quando você esquece que existe uma contradição capitaltrabalho que não sei se é uma visão clara, fica muito difícil você discutir Trabalho e Saúde.

Lacaz - Aqui se falou das questões das ideologias. Acho que a gente tá vivendo uma situação na qual essa questão das ideologias ficou muito obscurecida, essa contradição capital-trabalho, depois o pós-modernismo, né, parece que foi tudo sendo pasteurizado. Você, Peninha, falou em "vestir a camisa da empresa", não criar dificuldades no próprio trabalho, hoje essa questão do desemprego, a flexibilização e tal...

Peninha - Um médico de uma empresa, chegou prá mim e falou que o trabalhador hoje tem que manter a sua condição de empregabilidade!

Lacaz - Eu me lembro que quando eu assessorava a COMSAT (Comissão de Saúde e Trabalho) lá no Sindicato dos Químicos do ABC, recebíamos cartas das empresas com informação dos trabalhadores empregados. Elas diziam que estavam mandando a relação dos "colaboradores" da empresa. Aí quando era relação de trabalhadores demitidos, mudava, "estamos mandando a relação dos "operários" que foram demitidos", então muda. Quer dizer, quando você está lá vestindo a camisa, você é "colaborador", quando virou "bagaço" você deixou de ser colaborador. E isso tem a ver também com a discussão de que a relação Trabalho e Saúde, é carregada de uma carga política-ideológica que, hoje, na sociedade que a gente vive, está sendo obscurecida. Eu falo isso porque dentro da $\mathrm{ABRASCO}^{35}$, que é uma associação ligada à universidade, essa discussão foi sendo cada vez mais substituída pela discussão do Ambiente - a Saúde Ambiental - que é uma coisa mais fluida, a questão ideológica fica borrada. Eu acho que hoje a gente vive, na sociedade atual, uma "desideologização" e, com isso também, a discussão sobre a contradição capital-trabalho está sendo substituída por outras. O Chico de Oliveira ${ }^{36}$ outro dia colocava que a questão das

\footnotetext{
${ }^{35}$ Associação Brasileira de Saúde Coletiva.

${ }^{36}$ Lacaz refere-se à fala do Prof. Francisco de Oliveira, sociólogo, Professor Emérito da Faculdade de Filosofia Ciências Humanas e Letras da Universidade de São Paulo, em comunicação oral por ocasião de debate promovido pela Associação de Docentes da UNIFESP-EPM, realizado em 2001.
} 
desigualdades está sendo substituída pela questão das diferenças: as diferenças de gênero, a diferença étnica, a diferença religiosa, quando a questão central continua sendo a das desigualdades das condições de classe e ela está sendo cada vez mais obscurecida. E eu acho que isso tem influência sobre a produção científica nessa área, sobre o financiamento. $O$ Chico de Oliveira fala isso: as agências de fomento não têm interesse em financiar projetos que adotam uma linha marxista claramente hoje. Tudo está sendo substituído por novas relações, novas formas de apreender a realidade. Então tudo isso tem influência sobre a produção acadêmica, sobre os intelectuais, porque hoje, se você ainda advoga a postura mais crítica... As pessoas que eram do DIESAT vestiram a camisa do DIESAT, vamos dizer assim, mantiveram uma grande coerência, esse tempo todo. Outro dia alguém perguntou porque que eu nunca trabalhei em empresa. Eu falei que eu nunca trabalharia em empresa, e também nenhuma empresa me daria emprego, porque com a visão que a gente tem dessas questões, não há espaço em empresa nenhuma.

Peninha - Quer dizer que há uma concordância entre você e as empresas! [risos]

[Todos riem]

Lacaz - Concordância em não trabalhar! [risos]

Leny - Como falou o Herval, a discussão entre Trabalho e Saúde é maior que o DIESAT, obviamente, mas o DIESAT expressa, é um dos porta-vozes desse discurso contrahegemônico, e será que houve, principalmente naquele momento em que havia uma força, uma atuação maior dos sindicatos nessa área, uma mudança na prática das empresas, em função dessa ação dos sindicatos? O embate com as empresas nessa discussão? Hoje, me parece, com a situação que nós vivemos, como vocês falaram - desemprego, redução significativa de trabalhadores na base etc... - as coisas estão mais difíceis, mas...

Herval - Deixa eu acrescentar alguma coisa aí. Há alguns momentos que sugerem que houve, por exemplo, a redução dos acidentes típicos e a de doenças típicas do trabalho. Certamente, a prevalência e a incidência de silicose cairam, como cairam também a da bissinose $^{37}$, como a asbestose ${ }^{38}$ também deve ter caído. Até onde isso foi um consciência da classe patronal ou de...

Leny - Pode ser inclusive em função da mudança tecnológica...

Clemente - eu me lembro de uma discussão no Paraná - até o Ratinho ${ }^{39}$ foi nessa discussão pelo DIESAT - era a discussão sobre uma doença nova que estava vindo aí, que era tenossinovite e depois LER. Acho que foi começo dos anos 80. E a partir daí começa... Nós não tínhamos no sindicato nenhum trabalho com relação a essa doença. $\mathrm{O}$ registro que nós tínhamos entre os metalúrgicos era perda auditiva induzida por ruído, que era o primeiro lugar disparado, depois doenças pulmonares. Muitas doenças nunca tiveram registro. Hoje, a LER é a principal doença registrada entre os metalúrgicos e a principal em diversas outras categorias profissionais. Mas vamos ver essas outras citadas. $\mathrm{O}$ caso da bissinose. O que aconteceu com a indústrias têxteis de uma forma geral? Acabaram, acabaram de uma forma geral. Tem uma ou outra indústria têxtil ainda por aqui, no Brasil. As indústrias ligadas ao amianto. O que está ocorrendo aí, em termos de empresa. Reduziu-se drasticamente o contato, mas fisicamente, nos grandes centros industriais acabou-se a produção de amianto. E já, já, a mina de amianto, Minasul, poderá ir pro "beleléu". Só não foi ainda porque, no estado de Goiás, o segundo imposto é de lá... e para o sindicato local é um problema terrível, porque para ele, a mina representa 600 empregos. Mas a produção industrial do amianto está se restringindo. E posso falar que na metalurgia, a grande concentração de acidentes na

\footnotetext{
${ }^{37}$ Bissinose - doença pulmonar relacionada às poeiras de algodão.

${ }^{38}$ Asbestose - doença pulmonar grave, relacionada às poeiras de asbesto/amianto.

${ }^{39}$ Apelido de Gilberto Almazan, diretor do Sindicato dos Trabalhadores Metalúrgicos de Osasco e Região e do DIESAT.
} 
metalurgia, ainda é de acidentes típicos. Eles reduziram? Claro que reduziram, mas reduziram proporcionalmente à quantidade de trabalhadores na categoria. Então, isso está ocorrendo...

Herval - Você mudou a tecnologia. Você não produz, na indústria cerâmica, com os mesmos processos de misturação a céu aberto, você enclausurou esses processos. Aliás, esse problema é uma... não é que as indústrias e os empresários não saibam disso, mas eles colocam como se fosse redução com a intencionalidade de reduzir os acidentes de trabalho através de programas e tal, quando, na realidade, a redução se deveu a outros determinantes, à concorrência, por exemplo. É problema de concorrência e de tecnologia. Nunca houve e nem nunca terá preocupação de empregador com saúde do trabalhador.

Clemente - Na região de Osasco, quando realizamos a Segunda SEMSAT, nós tínhamos em torno de 8 mil trabalhadores trabalhando em fundição, 6 mil trabalhadores em caldeiraria; hoje, nós não temos 300 trabalhadores em fundição e em caldeiraria, talvez, tenha uns 300, 400. As empresas fizeram o seguinte. Fundição realmente, as grandes fundições acabaram. Elas, hoje, buscam serviços em outros lugares, mas caldeiraria, as empresas que trabalhavam com caldeiraria, algumas fecharam, mas outras elas perceberam que manter a caldeiraria dentro delas era um mau negócio. Por exemplo, empresa de alta tecnologia, como a ASEABrown Bovery, que é uma empresa sueco-suíça, ela percebeu que o meu negócio não é a caldeiraria, o seu negócio é produzir a tecnologia para o motor. Ela foi desenvolvendo os protótipos e foi terceirizando, primeiro na própria região de Osasco, e agora temos notícias de terceirização em outros estados. Então, o risco tem sido transferido para outras empresas e onde as empresas ficaram realmente fazendo o trabalho ela investiu em tecnologia e diminuiu o risco para os trabalhadores. Olha, naquela época nós tínhamos sete empresas com mais de mil funcionários, hoje nós temos, na nossa base, duas empresas com mais de mil funcionários. Dessas duas, uma tem, na produção mesmo, menos de 500.

Herval - Você está colocando um panorama que faz com que reduza os acidentes de trabalho típicos, como também aponta para uma situação nova que é a mudança do perfil epidemiológico das doenças do trabalho hoje. E tem aí os riscos psico-afetivos. E aí eu perguntaria até, aí vai uma sugestão: uma próxima SEMSAT sobre "Medo e Trabalho".

Peninha - Aliás, é bom colocar aqui que nós estamos planejando, no DIESAT, para a terceira semana de setembro, retomar a SEMSAT. Adotarei a sugestão...

Leny - A construção de uma leitura em Saúde do Trabalhador, pelo movimento sindical e o DIESAT como sendo uma possibilidade de materializar esse discurso, dar voz a uma outra visão - acabou conduzindo a mudanças em termos de legislação, em termos de condição de trabalho ou o reconhecimento de uma doença, a LER é um caso que expressa muito isso, começa com uma articulação no Rio Grande do Sul, acho que no sindicato dos bancários...

Peninha - Nos SINDPDs ${ }^{40}$.

Leny - E que mostra como uma lesão tem um reconhecimento, uma visibilidade em função de uma luta que é feita...

Herval - Pelo movimento sindical.

Peninha - Pelo movimento sindical.

Leny - Exatamente, pelo movimento sindical.

Lacaz - A dissertação da Lys [Esther Rocha] mostra isso.

\footnotetext{
${ }^{40}$ Sindicatos de Trabalhadores de Processamento de Dados.
} 
Peninha - Exatamente. Veio do pessoal de processamento de dados, que entrou nessa luta, inclusive, digamos, a nossa fada madrinha, cientificamente falando, é a Lys, mas isso realmente começa exatamente quando ali aparece, onde se externa a causalidade da LER com a organização do trabalho.

Leny - Porque eu me lembro que quando fizemos a pesquisa dos bancários em 1985, pelo DIESAT, nós entrevistamos os trabalhadores que exerciam algumas funções e eu me lembro que naquela altura tinha um caixa que foi entrevistado e que se queixava de ter dor no pulso... Naquela época, a tenossinovite era conhecida em digitadores, você tinha, nos bancos, os serviços de compensação bastante grandes ainda. Naquela época, ter um funcionário que trabalhasse no caixa com tenossinovite era uma coisa ainda incipiente. E aí começa a se disseminar esse problema entre os caixas de uma forma geral.

Peninha - E aí, depois do reconhecimento da doença, você tem um movimento a nível nacional, que desembocou em 1990, às vésperas da mudança de governo, na edição de uma portaria que altera a Norma Regulamentadora 17 exatamente no que se refere à organização do trabalho, mas isto na parte de entrada eletrônica de dados ${ }^{41}$. E essa portaria acabou não sendo editada, retiraram da publicação, ela estava para ser editada, no final acabou sendo editada, seis meses depois, em fevereiro de 1991, que estabeleceu jornada máxima, introdução de pausas, número máximo de toques por hora, necessidade de esperar o trabalhador readquirir o ritmo quando da volta de férias ou licença. Então isso aí realmente mexe na organização do trabalho. Mas ela também tinha outros detalhes que se referiam ao equipamento e ao mobiliário, iluminação. As empresas reclamaram e só entrou realmente em vigência, a parte referente à organização do trabalho. E nós percebemos, tempos depois, em uma das empresas que era da base, que somente esse fator era responsável por uma redução no número de casos novos de LER, considerada a diminuição da população de risco também, da ordem de 60\% aproximadamente, no mínimo. Demonstrou-se ali, talvez o primeiro caso de uma doença do trabalho, como importante causa, uma relação mais direta com a organização do trabalho... Eu falo da situação específica da categoria de processamento de dados, mas a LER se expandiu para outras categorias profissionais. Mas nós estávamos falando do histórico aqui, de como os sindicatos, o DIESAT participaram de mudanças. Muitos acordos, convenções coletivas, comissões bi-partites inter-categorias que tratam especificamente de problemas de determinadas categorias. Existem algumas como o uso de cilindros nas padarias, das prensas injetoras, das lavanderias, dos condutores e por aí adiante vai, e o DIESAT colaborou em várias delas, mesmo na década de 90, nessa década que foi quase o fim do DIESAT.

Leny - Tem também um outro caso no qual eu participei, o Lacaz também participou pelo DIESAT quando ele trabalhava nos Químicos do $\mathrm{ABC}$, que é o caso do mercúrio em uma indústria de cloro-soda, foi em 1987. Esse também foi um caso interessante no qual houve uma articulação inter-institucional, tinha o DIESAT, o Sindicato dos Químicos do ABC, o Centro de Referência em Saúde do Trabalhador de São Bernardo, a Secretaria de Estado da Saúde, Fundacentro ${ }^{42}$, Ministério do Trabalho, Hospital das Clínicas etc... Foi um caso em que, a partir de lá, "levantou-se a bola" prá discutir o caso do mercúrio em indústria de lâmpada... Em Osasco teve caso de empresa de lâmpadas, em São Paulo também.

Lacaz - Esse caso está relatado no livro Insalubridade - morte lenta no trabalho. Inclusive, depois desse episódio, a empresa mudou de nome: de Eletrocloro para Solvay do Brasil.

Clemente - No caso de Osasco, é a Osram, em 1991. Eu lendo o jornal, uma notícia de jornal sobre a fiscalização do Ministério do Trabalho numa indústria de lâmpada, a Silvânia

${ }^{41}$ As Normas Regulamentadoras estão incluídas na Consolidação das Leis do Trabalho, aprovadas pela Portaria no. 3.214 de 8 de julho de 1978, no Capítulo V do Título II, relativas à Segurança e Medicina do Trabalho.

${ }^{42}$ Fundação Jorge Duprat Figueiredo de Segurança e Medicina do Trabalho. 
em São Paulo, com a Cecília Zavariz ${ }^{43}$. Foi uma leitura de jornal. Nós fizemos um levantamento na empresa, a Fundacentro participou para fazer a calibração dos equipamentos que a empresa tinha para medir o mercúrio, equipamentos que a empresa havia trazido, o Centro de Referência de Saúde do Trabalhador da Lapa, o Centro de Reabilitação Profissional (CRP) e o Serviço da Perícia do INSS ${ }^{44}$. Em 1991 levantam-se os casos. Eram mais de 100 casos com pessoas contaminadas com mercúrio. $\mathrm{O}$ desdobramento daquilo, num levantamento feito, foi um número enorme de pessoas encaminhadas ao CRP. A empresa encaminhou os trabalhadores para serem avaliados na Unicamp, imagina que eles encaminhavam para Campinas, e nisso nós tivemos alguns embates lá... Hoje ela é apenas uma embaladora de lâmpadas que são fabricadas no exterior.

Lacaz - Tem uma questão que o Clemente tocou, que é a visão que os sindicatos tinham na época, a visão assistencialista, que os sindicatos fazem, faziam. Eu acho que o DIESAT teve um papel muito importante em mostrar os limites daquela visão assistencialista que os sindicatos tinham, que é reproduzir uma lógica medicalizante, de atender o trabalhador, dar medicação e o trabalhador voltava para casa. O DIESAT fez uma discussão de que isso deveria ser modificado, e mesmo os serviços de assistência dos sindicatos deveriam ter uma outra visão, que era pensar que aquelas queixas que os trabalhadores traziam poderiam ter relação com o trabalho que ele executava, então isso foi mudando o perfil dos próprios serviços dentro dos sindicatos. No Sindicato dos Químicos isso aconteceu. Inclusive, isso originou a discussão do Programa de Atenção à Saúde do Trabalhador no ABC, porque o sindicato, pressionado pela base, inclusive porque a base quer o médico, o sindicato extinguiu, praticamente o seu serviço médico e deu como alternativa o serviço público e negociou com a Secretaria de Saúde. Acho que esse processo foi uma das coisas mais rápidas, em que o aparelho de Estado assume porque teve o sindicato propondo, acompanhando, sugerindo, e depois, também avaliando. Uma coisa muito interessante.

Herval - Pela primeira vez, e talvez a única, houve um processo de seleção de médicos e profissionais de saúde em que teve a participação do sindicato na escolha dos profissionais. É uma coisa inédita. É daí, dessa experiência que foram gerados os Programas de Saúde do Trabalhador, só que com uma perversão - que no momento, o movimento sindical não teve fôlego para perceber que era uma perversão - que é o Estado se apropriar de uma proposta que era do movimento sindical de ter os Programas de Saúde do Trabalhador autônomos e que o Estado atuaria respeitando a autonomia do processo. Nesse particular o Estado se apropria da proposta e cria programas em todo o estado de São Paulo, sem a iniciativa do movimento sindical...

Lacaz - Não precisava ter base social, né?

Herval - É, pois é! Você delegou... e aquela estória... virou serviço! Quer dizer, quando você transforma uma proposta política de trabalhar essa questão... mesmo que tenha alguns ganhos, ela passa a ser submetida ao poder do Estado. E aí eu volto a uma questão, para que não se confunda ideologia e consciência política com partidarismo. Nesse particular, nessa ocasião, o $\mathrm{PCB}^{45}$, já esquálido, teve um papel nessa proposta de o Estado assumir essa circunstância, tanto que os Programas de Saúde do Trabalhador sempre foram assumidos por quem esteve vinculado ao PCB da época. Isso vale também para uma coisa que é mérito do DIESAT. Apesar de ter uma ideologia claramente de esquerda, nunca se deixou contaminar partidariamente e mesmo ideologicamente pelo que fazia. O produto do que o DIESAT fazia, fazia para sindicatos de diversas orientações político-partidárias e para as centrais. Ainda que os técnicos pudessem ter suas posições político-partidárias, eles não se deixaram contaminar por esses posições. Dentro da linha que, de certo modo, é do próprio

\footnotetext{
${ }^{43}$ Médica e auditora fiscal do trabalho da Delegacia Regional do Trabalho de São Paulo do Ministério do Trabalho e Emprego.

${ }^{44}$ Instituto Nacional de Seguridade Social.

${ }^{45}$ Partido Comunista Brasileiro.
} 
DIEESE; ou seja, você produz um conhecimento para que os sindicatos usem como desejarem. O que se produzia para um sindicato chamado de "pelego" - que no caso do DIESAT nunca foi, o Sindicato dos Metalúrgicos de São Paulo, na ocasião - se produzia para um sindicato de esquerda, no caso o Sindicato dos Metalúrgicos de São Bernardo do Campo. Essa visão de um conhecimento que não é neutro, mas que não é partidário, é um dos grandes méritos do DIESAT. Ele permaneceu e permanece hoje.

Clemente - Não pode ficar vinculado a uma central.

Peninha - É suprapartidário. E também, eu acho que apesar de tudo, criou-se e aumentou a consciência dentro das centrais de que não basta ter aquele instituto ligado à própria central, e sim um órgão que faça a interlocução entre todas as correntes do movimento sindical e que atua politicamente, porém apartidariamente, levando as questões de Saúde do Trabalhador. Isso daí, eu acredito, pela experiência que eu tenho tido, nesses anos que eu tenho estado no DIESAT, inclusive por acompanhar uma fase bastante difícil da entidade, eu posso dizer que eu tenho certeza que existe, no momento, a consciência da importância de um órgão supra-partidário. É uma das maiores certezas que eu carrego hoje como dirigente do DIESAT.

Leny - Mas isso que vocês falam, né, vocês acham que isso redundaria num apoio material, financeiro, um apoio efetivo. Vocês falaram no início, na época das primeiras SEMSATs de irem a vários sindicatos, falar sobre o trabalho e as intenções do DIESAT?

Clemente - Chapéu na mão...

Leny - Isso, chapéu na mão ou sensibilizar a direção sindical para chamar discussões com a base. Vocês acham que é possível hoje?

Clemente - Eu vejo a dificuldade de financiamento, mas a gente vive uma experiência de atuação intersindical em Osasco. Existe um Conselho Intersindical. Nó temos 32 sindicatos que têm base ou sede na região. $\mathrm{O}$ presidente do conselho nos últimos anos é ligado à CUT. A gente consegue, com todas as dificuldades, a gente consegue, devagarzinho, pautar os principais questionamentos da região nesta área, e a coisa anda, a Conferência de Saúde do Trabalhador aconteceu na semana passada. Quem pontuou as questões foi o conselho. Se a gente puser as centrais à frente dessas discussões, não há espaço. $\mathrm{O}$ acumulado dessa discussão não está nas centrais sindicais.

Peninha - É bastante semelhante ao que ocorre na Plenária de Saúde do Trabalhador aqui de São Paulo. Organizou duas Conferências Municipais de Saúde do Trabalhador e quem organizou foram as entidades e a Plenária. E dentro da Plenária, realmente, não se fala em centrais, são sindicatos vinculados a centrais, mas não existe interferência das centrais nessa discussão.

Herval - O próprio SUS, o Sistema Único de Saúde, é uma questão pouco discutida pelas centrais.

Leny - Eu queria me referir ao período em que participei do DIESAT. Naquele momento havia demanda para realizar discussões, pesquisas sobre subjetividade e trabalho, saúde mental e trabalho, então, a participação da Edith foi muito importante lá e a gente teve oportunidade de trabalhar com ela e com a Agda, foi interessante com os bancários e com os metroviários pois essas experiências falam também da forma como o DIESAT trabalha. Não só nas pesquisas, mas o tempo todo os estudos realizados eram feitos com a participação de um grupo composto por sindicalistas ou trabalhadores eleitos pela base para representálos, para participar daquelas pesquisas, que era pesquisa participante e o Brasil tem aí um mestre, Paulo Freire, super reconhecido fora do Brasil também. E essa influência é forte. E também uma outra área em que as disciplinas "psi" também são solicitadas é no caso do 
mercúrio e outros agentes neurotóxicos - porque o mercúrio provoca efeitos neuropsicológicos - toda a avaliação nessa esfera que visava detectar os possíveis efeitos da intoxicação. E uma outra experiência que nós nem tivemos tempo de falar aqui - além das pesquisas e das assessorias mais pontuais, como estudos -, eu, particularmente, tive a oportunidade de participar de muitos cursos de formação sindical, que é uma atividade muito importante, tanto no sentido de ser um espaço no qual se resgata o conhecimento que o trabalhador tem a partir da vivência dele no dia a dia de trabalho e, num curso, o trabalhador não está isolado, mas começa a discutir com os colegas e, aquilo que a princípio parece que é um problema que é só dele, ele que é "fraco", ele é que é "problemático", num espaço coletivo ele começa a perceber que não é isso, mas que tem outras pessoas que vivem situações de trabalho comuns e que têm os mesmos problemas: com a família, de saúde. Então, essa atividade que nós fazíamos, com o Nilton Freitas ${ }^{46}$, com a Agda [Aparecida Delia] e com outras pessoas, em sindicatos diferentes...

Peninha - O DIESAT está fazendo cursos com dirigentes de sindicatos ligados a uma federação. Por outro lado sempre nos requisitam muitos cursos de CIPA, inclusive na nossa base. O nosso problema é atender essa demanda, a gente não tem como atender a essa demanda.

Leny - Hoje o DIESAT tem um assessor técnico?

Peninha - Sim, um. E conta com aquela base que são vocês, membros do Conselho Científico. O DIESAT faz perícias, participou da pesquisa-ação em Saúde Mental e Trabalho, perícias principalmente nas empresas da área energética, tem o convênio com o $\mathrm{ICEM}^{47}$, que é um convênio de formação sindical, feito pelo Brasil inteiro. Inclusive foi incluído num projeto a edição revisada e ampliada do livro De que adoecem e morrem os trabalhadores. O Wilson Campos, que participa do Conselho Científico, tem colaborado conosco não só no contato nosso com o ICEM, mas tem colaborado com material. São basicamente duas pessoas que têm trabalhado na resposta a essas demandas. Existe a viabilidade de o DIESAT abrir uma sede regional em Curitiba; existe, inclusive, o espaço físico. Tem técnicos que querem fazer pesquisas e perícias lá. Precisa fazer o contato com as entidades sindicais do Paraná para que elas dêem o apoio, existe já a disponibilidade, mas precisa ser efetivado. São essas perspectivas que têm. Na verdade, quando nós assumimos a direção da entidade na gestão passada era prá fechar a entidade, mas agora parece que mudou.

Lacaz - A regional do DIESAT no Rio de Janeiro, não tem mais?

Peninha - No Rio, na verdade, está sendo reativado. Em 2000, na época da eleição da diretoria tinha mais cargos do que candidatos. Na gestão passada conseguimos arrumar as finanças e a casa em curto prazo. Por conta até de termos entrado na luta do Seguro de Acidentes de Trabalho, de estarmos envolvidos em outras questões, como a saúde mental mesmo, participou de dois Fóruns Sociais Mundiais, com mesas de debates. Dessa vez, nessa nova eleição de diretoria, nós inclusive tivemos um maior número de candidatos e não tinha vaga para ocupar os cargos da diretoria. Um dos membros da atual diretoria, do Rio de Janeiro, está reivindicando reabrir o DIESAT no Rio, o Odilon, do Sindicato dos Petroleiros. Existe inclusive pessoal disposto a atuar na área técnica. Por isso que eu digo que há cada vez mais consciência da necessidade de um órgão intersindical nessa área. Por que isso foi pedido pelo Rio de Janeiro e pelo Paraná. Existe uma diretoria nova, gente que está entusiasmada. Eu acho que nós temos condições daqui prá frente, apesar de todos os percalços, apesar de todo o problema que tem tido no movimento sindical...

Leny - Muito embora o leitor dessa entrevista possa tomar contato com os trabalhos do

\footnotetext{
${ }^{46}$ Engenheiro, foi assessor técnico do DIESAT e da CUT, atualmente é presidente da Fundacentro.

${ }^{47}$ Federação Internacional de Sindicatos de Trabalhadores da Indústria Química, Energética, Minas e Diversos.
} 
DIESAT através do próprio órgão, valeria à pena, Lacaz, que você falasse um pouco mais sobre a atuação do DIESAT na época da Assembléia Nacional Constituinte, na qual a Edith teve um papel importante com relação à questão do trabalho em turnos alternados. Tem também a proposta de estruturação das COMSATs nos sindicatos. Você trabalhou muito tempo, o Nilton [Freitas] também, na época que o Remi [Remígio Todeschini] era diretor lá, no Sindicato dos Químicos do ABC.

Lacaz - No processo constituinte o DIESAT elaborou textos, participou de comissões, teve, inclusive, uma SEMSAT que discutiu temas da Saúde do Trabalhador para a Constituinte. Dentre esses temas, a do trabalho em turnos, novas tecnologias, os programas de saúde do trabalhador. A COMSAT era constituída de dirigentes sindicais, militantes e da assessoria técnica. Na época trabalhava eu e o engenheiro Nilton Freitas, com o suporte da assessoria jurídica do sindicato. O objetivo dessa comissão era assessorar o sindicato em negociações junto às empresas, analisar informações para a sua divulgação nos boletins gerais e específicos, atuar em formação sindical em saúde, discutir e fazer cumprir direitos trabalhistas e previdenciários, fazia avaliação de ambientes e condições de trabalho a partir de negociações entre o sindicato e as empresas. Quer dizer, o objetivo era sempre o de prevenir os problemas de saúde no trabalho e transformar as demandas individuais em questões coletivas, como foi o caso do benzenismo na Indústria Matarazzo e na Petroquímica União, o do hidrargirismo na Solvay do Brasil, o do saturnismo na Ferro Enamel etc...

Leny - Teria muitas e muitas coisas a falar, poderíamos falar por muitas horas, mas acho que podemos fazer uma rodada final.

Clemente - Foi legal a gente poder se reunir novamente. Na verdade, eu ando afastado, mas o nosso sindicato sempre participa do DIESAT, desde 79. Sempre apostei em formação de novos quadros. O pessoal tem ocupado esses espaços aí, o Ratinho e outras pessoas. Estou hoje convicto, passados 24 anos do início do movimento, que a solução ainda, para a questão de saúde do trabalhador é ter uma entidade intersindical forte nessa área, não tenho dúvida. Passei por inúmeras experiências e eu acho que a melhor alternativa prá gente é ter um movimento forte nessa área intersindical porque a partir daí você vai poder irradiar... É isso. E já se falava naquela época que se os trabalhadores não assumirem a luta pela saúde ninguém vai fazer isso por eles.

Lacaz - Eu acho que é isso que a gente falou. Teve esse trabalho, muitas vezes, contra a corrente, a gente atuou bastante prá construir o DIESAT. Eu senti no meu último vínculo, pelo DIESAT, no Sindicato dos Químicos do ABC, que teve um patamar de luta bastante avançado. Talvez tenha sido um dos sindicatos que mais atuou nessa área. Mas, de uns tempos prá cá, o que eu percebi é que o sindicato retrocedeu na questão coletiva, nas questões mais gerais, e voltou-se para uma atuação sobre os processos de insalubridade, de atendimento individual, então isso me deixou bastante desconfortável, tanto que eu acabei saindo, questão interna do sindicato, problemas financeiros, tal. Mas eu acho que essas coisas que vocês estão colocando, é alvissareiro, o pessoal do Paraná, é um pessoal de "pique", um pessoal mais à esquerda.

Herval - Eu acho que essa reunião aqui de hoje não é uma reunião de memória, mas sim de saber onde nós estamos e como está o órgão que nós ajudamos a criar, no qual nós continuamos incluídos ${ }^{48}$. A vida nos chama para outros debates, mas não deixa de ser, sobretudo, confortador saber que as pessoas estão em lugares, em situação de fronteira de inquietação, é muito confortador.

\footnotetext{
${ }^{48}$ Herval, Lacaz e Leny fazem parte do Conselho Científico do DIESAT, juntamente com Arline S. A. Arcuri, Antonio José de Arruda Rebouças, Carlos Minayo Gomez, Idelberto Muniz de Almeida, Leda Leal Ferreira, Luiz Augusto Facchini, Tereza Mitsunaga Kulezka, Vicente de Paula Faleiros, Victor Wünsch Filho e Wilson Campos.
} 
Peninha - Bom, acho que o fundamental que eu queria colocar, e concordando com o Clemente, é isso mesmo. Tem a necessidade de ter um órgão intersindical e tem que ser forte e o movimento sindical tem que se conscientizar cada vez mais disso, porque só assim que a gente vai conduzir ao avanço da Saúde do Trabalhador. Posso dizer que tem algumas coisas que são alvissareiras. Há órgãos governamentais que têm procurado o DIESAT. E é "tocar o bonde" por aí.

Leny - Essa é uma entrevista para uma revista de Psicologia a qual adota uma perspectiva na qual procura manter interlocução com outras disciplinas e com o movimento social, buscando estar atenta aos problemas contemporâneos do trabalho no Brasil. Eu acredito que tenha sido possível, ao leitor, apreender um pouco dessa história que não fala apenas do DIESAT, mas fala também do próprio movimento sindical e de como a construção do conhecimento científico pode ser feita em constante interlocução com as necessidades sociais, através dos movimentos sociais. Para a psicologia, adentrar à temática da Saúde do Trabalhador, que não é sinônimo de Saúde Ocupacional, como bem mostrou o Lacaz na sua tese, certamente abre uma perspectiva crítica. Foi muito bom rememorar e conhecer melhor o DIESAT. Muito obrigada. 